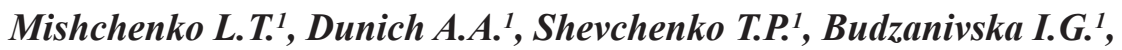
Polischuk V.P. , Andriychuk O.M. ${ }^{1}$, Molchanets O.V. , Antipov I.O. ${ }^{2}$

\author{
${ }^{I}$ ESC 'Institute of Biology and Medicine', Taras Shevchenko National University of Kyiv, \\ Volodymyrska str., 64/13, Kyiv, 01601, Ukraine \\ ${ }^{2}$ National University of life and environmental sciences of Ukraine, \\ Heroyiv Oborony str., 15, Kyiv, 03041, Ukraine
}

\title{
DETECTION OF SOYBEAN MOSAIC VIRUS IN SOME LEFT-BANK FOREST-STEPPE REGIONS OF UKRAINE
}

Soybean (Glycine max L.) is strategic legumes world crop of XXI century, which is located in the center of attention of world agricultural science and production. Soybean mosaic virus (SMV) is the most prevalent virus and is recognized as the most serious, long-standing problem in many soybean producing areas in the world. Infection by SMV usually results in severe yield losses, seed quality, seedling viability reduction of soybean. Study of soybean viruses in Ukraine were conducted exclusively on the Right Bank of its parts. However, studies of possible spreading and circulation of these viruses in a left-bank forest-steppe has not yet been carried out. The aim of the study was to diagnose of viruses that infect soybeans in the territory of left-bank Ukraine, and investigate some of their properties. Methods: visual diagnostics, transmission electron microscopy, ELISA, RNA extraction from plant material, PCR, sequencing, phylogenetic analysis. Results. It was studied 29 samples of soybean plants in the territory of left-bank forest-steppe of Ukraine (Poltava, Sumy and Kharkiv region) on the presence of a viral infection. ELISA revealed that 48\% of the samples (13 samples from the Poltava region and 1 -from Sumy) affected with Soybean mosaic virus. This is the first report about infecting soybean grown in a leftbank of Ukraine with SMV. On the basis of previously submitted data on circulation in the territory of the right bank of the country mixed infection of this virus with Bean yellow mosaic virus $(B Y M V)$ and Alfalfa mosaic virus $(A M V)$, the test samples were checked on the presence of these viruses. Results of the analysis showed the absence of BYMV and AMV antigens. It was found that the studied SMV isolates differ in virions size from the previously identified Ukrainian SMV isolates. Phylogenetic analysis of the nucleotide sequence of the capsid protein gene of Soybean mosaic virus showed a 100\% level of phylogenetic relatedness between the Ukrainian representative isolate and Chinese, Iranian isolates, American isolate 452, and Polish isolate M, which testifies to their common origin.

Keywords: Glycine max, Soybean mosaic virus, Bean yellow mosaic virus, Alfalfa mosaic virus, ELISA, PCR, sequencing, viruses morphology, phylogenetic analysis.

Soybean mosaic disease was first documented in the USA in 1915 [1] and its viral etiology in the detail was described by Gardner and Kendrick [2]. Since then, the virus has been found in China, Japan, South Korea, Canada, Brazil, Australia and other countries where soybean is grown, and in Ukraine [3-5].

Now it is known that soybean mosaic disease is caused by Soybean mosaic virus (Potyvirus, Potyviridae), and that it is the most widespread and is recognized as the most serious, long-standing problem in many soybean producing areas in the world [6]. Infection by SMV usually results in severe yield losses from $8 \%$ to $50 \%$ [7] under natural field conditions and reach up to $100 \%$ in 
severe outbreaks [8]. SMV-infection can cause change chemical composition of the seed, reduce seedling viability [9] and cause seed coat mottling.

Since SMV is a seed-borne viral pathogen and aphids efficiently spread it from plant to plant while they feed, it is difficult to control the virus and produce SMV-free seeds. Furthermore, SMV often infects soybeans with other viruses: Bean pod mottle virus, Alfalfa mosaic virus, Tobacco ringspot virus $[6,10]$ and Bean yellow mosaic virus [4]. The most effective and efficient measures to protect plants against viral diseases that interrupt the circulation of the virus in soybeans and significantly reduce their harmfulness is timely diagnostics of diseases, creation and cultivation of resistant soybean varieties and the use of virus-free seed.

First report about SMV in Ukraine was in 1938. Later this virus was detected in soybean fields in eastern and southern regions [3]. A more detailed study of the properties and origin of the Ukrainian SMV isolates were conducted in 2011-2012 only on the right bank part of Ukraine. Thus, a mixed infection of SMV with Bean yellow mosaic virus [4] and Alfalfa mosaic virus [10] in soybeans in Kyiv, Cherkassy and Vinnitsa regions was detected. However, a detailed study of viruses' circulation in soybeans under natural conditions of left-bank forest-steppe has not yet been carried out.

In view of the above, the aim of the study was to conduct the diagnostics and identification of viruses that infect soybeans in the territory of left-bank Ukraine, and investigate some of their properties.

Materials and methods. Plant samples with disease symptoms of a viral etiology were selected for soybean crops in Poltava, Kharkiv and Sumy regions [11].

Biological tests carried out by mechanical inoculation of indicator plants in phase two true leaves with sap of infected soybeans.

Morphology of virus particles was determined by transmission electron microscopy method. Contrasting has been made with $2 \%$ solution of phosphorustungstic acid [12]. Virions are investigated using electron microscope JEM 1230, 1400 (JEOL, Japan).

Double antibody sandwich enzyme-linked immunosorbent assay (DASELISA) with anti-SMV-IgG, anti-BYMV-IgG and anti-AMV-IgG («Loewe», Germany) were used for viruses identification. The results of reaction registered on the reader (Termo Labsystems Opsis, USA) with Dynex Revelation Quicklink software at lengths of waves of 405/630 nm. All samples showing values three times higher than the negative control are assumed as virus positive [13].

Total RNA was extracted from virus-infected soybean leaves using the Genomic DNA purification kit (Thermo Scientific, USA). The results were checked by RNA electrophoresis in 1.5\% agarose gel used as a dye ethidium bromide solution at the concentration of $0.5 \mathrm{mg} / \mathrm{ml}$.

RT-PCR was carried out using Qiagen one Step RT-PCR kit+Q-solution (Qiagen, USA) and thermo cycler (Genetic research instrumentation LTD, UK).

A pair of the specific oligonucleotide primers: SMV1 (5' tgcagcagaagcttacattga 3'), SMV2 (5' tgttaactcccgagagagctg 3') were used for amplification of the part (194 bp) of the SMV capsid protein gene. Places of primers annealing 
have noted the example of the nucleotide sequence of isolate which is included in the GenBank under accession number GU015011.1.

Thermal cycling conditions were: $95^{\circ} \mathrm{C}$ for $15 \mathrm{~min}, 95^{\circ} \mathrm{C}$ for $30 \mathrm{~s}, 56^{\circ} \mathrm{C}$ for $30 \mathrm{~s}, 72^{\circ} \mathrm{C}$ for $1 \mathrm{~min}, 72^{\circ} \mathrm{C}$ for $5 \mathrm{~min}$. Analysis of PCR amplification products was performed by electrophoresis in $1.5 \%$ agarose gel using a DNA marker Gene Ruler Plus 100 bp (Fermentas, USA) [14].

Amplification products (cDNA) were purified using a set of reagents High Pure PCR Product Purification Kit (Roche Applied Science, Germany). Sequencing of purified amplified fragments was performed on the Applied Biosystems 3730x1 DNA Analyzer with Big Dye terminators, version 3.1 (Applied Biosystems, USA).

Identification and comparison of the sequence with sequences of SMV isolates from GenBank were performed using BLAST analysis (http:// www.ncbi.nlm.him.gov). The phylogenetic analysis was performed using MEGA 7 software. Phylogenetic tree was constructed by maximum likelihood algorithm (ML). Bootstrap test with 1000 bootstrap replications was used to check the reliability of the constructed trees.

Statistical analysis of experimental data was performed by parametric criteria of normal distribution option, the standard deviation of the mean values with the conventional method using computer programs MS EXCEL [15].

Results. In 2015 observation of soybean crops in the fields in Poltava, Sumy and Kharkiv regions showed symptoms of leaves rugosity, clearly marked dark green bloating between the veins (Fig.1).

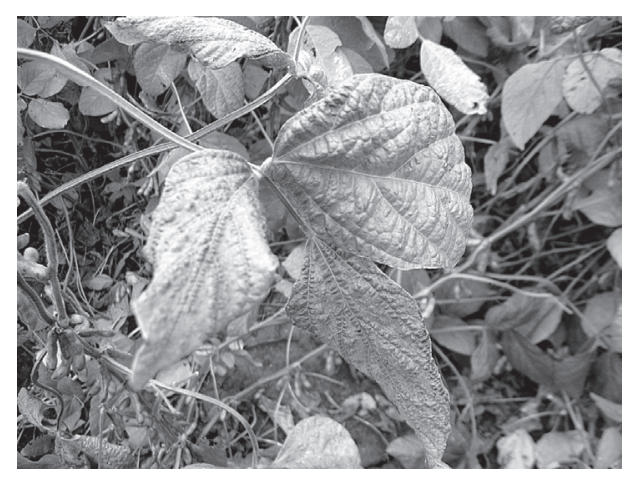

1

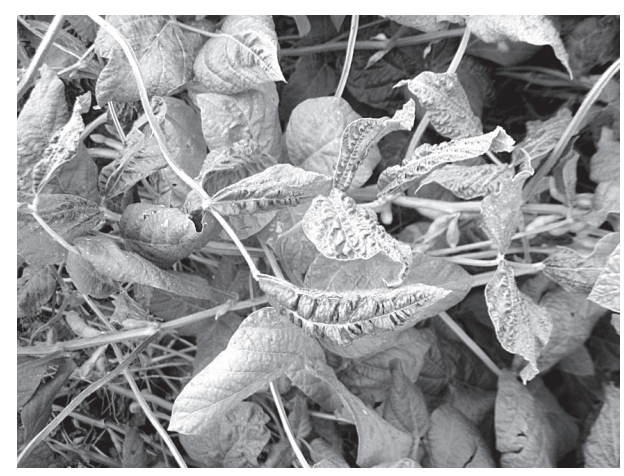

2

Fig. 1. Symptoms of rugosity and clearly marked dark green bloating on the leaves: 1 - sample № 27, Sumy region; 2 - sample № 17, Poltava region

Plants with specified symptoms (29 samples) were selected for further studies.

According to the scientific literature symptoms similar to we have identified may cause Soybean mosaic virus, Alfalfa mosaic virus and Bean yellow mosaic virus $[4,10]$.

In order to identify a pathogens detected in soybean was preformed ELISA using antisera to viruses that are common to this culture in the world and are found in Ukraine, as well as similar morphological characteristics (Soybean mosaic virus (SMV), Alfalfa mosaic virus (AMV) and Bean yellow mosaic virus (BYMV).

The analysis showed that $48 \%$ of selected samples contained antigens of 
Soybean mosaic virus (SMV), the largest number of the tested samples were selected in the Poltava region (samples №№ 2, 3, 5, 9,10, 12-15, 17-19 and 21) (Fig. 2). Only the one sample (№ 27), containing SMV antigens was detected on the territory of Sumy region (Fig. 3).

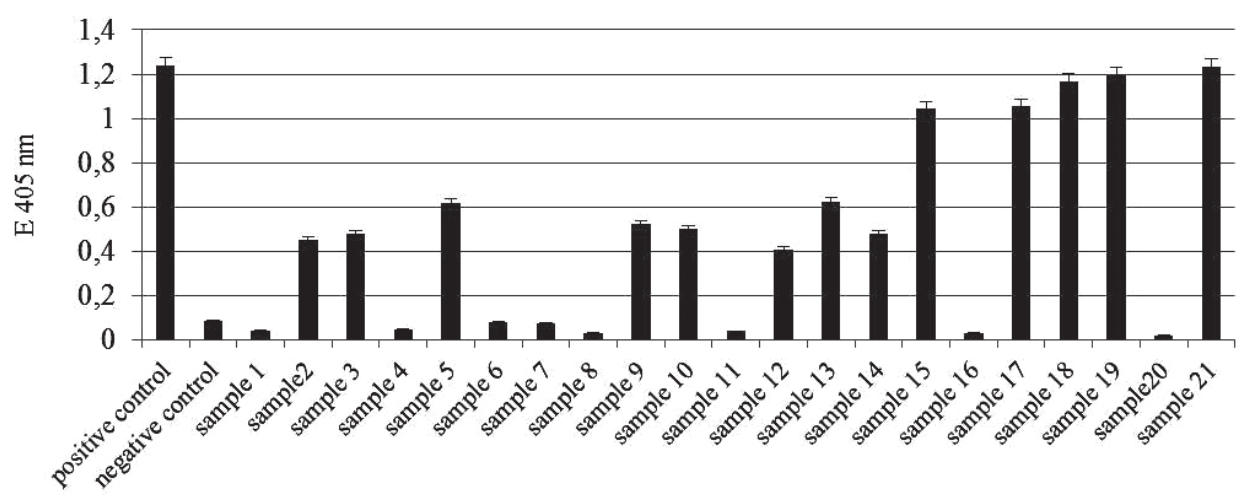

Fig. 2. Content of the Soybean mosaic virus antigens in soybean samples, Poltava region

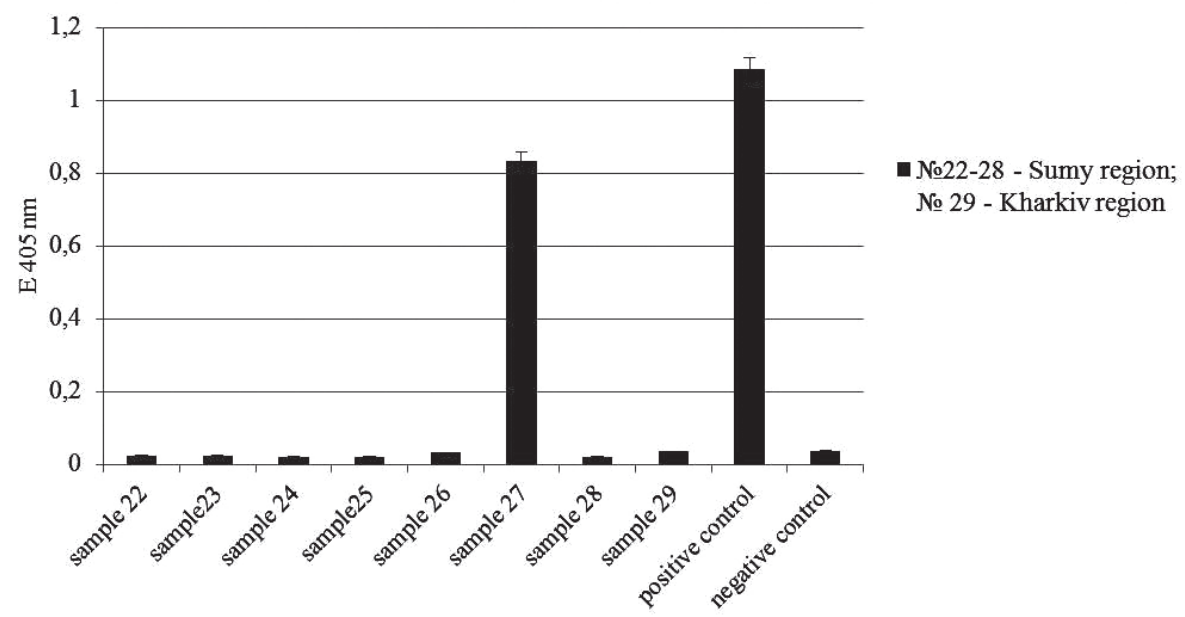

Fig. 3. Content of the Soybean mosaic virus antigens in soybean samples, Sumy and Kharkiv region

This is the first report about SMV affecting of soybeans grown in left-bank forest of Ukraine.

Due to the reports of soybean infection in Ukraine with Alfalfa mosaic virus and Bean yellow mosaic virus studied samples were tested on the presence of these pathogens. ELISA results showed no antigens of BYMV and AMV in all tested samples.

The electron microscopy method revealed that the studied isolates of Soybean mosaic virus are filamentous virus particles. However, they differ greatly in virions length depending on the soybean sample. It was found three modal lengths of viral particles: $530-550 \mathrm{~nm}, 620-650 \mathrm{~nm}$ and $800-820 \mathrm{~nm}$ with a width of 14-17 nm (Fig. 4).

Morphology of investigated SMV isolates is similar to viruses from genus Potyvirus, Potyviridae, which are filamentous virions $(680-900 \times 11-13 \mathrm{~nm})$. According to the literature previously isolated Ukrainian SMV isolates have $650-750 \times 17-18 \mathrm{~nm}[10]$ and 700-760 $\mathrm{nm}[4]$. 

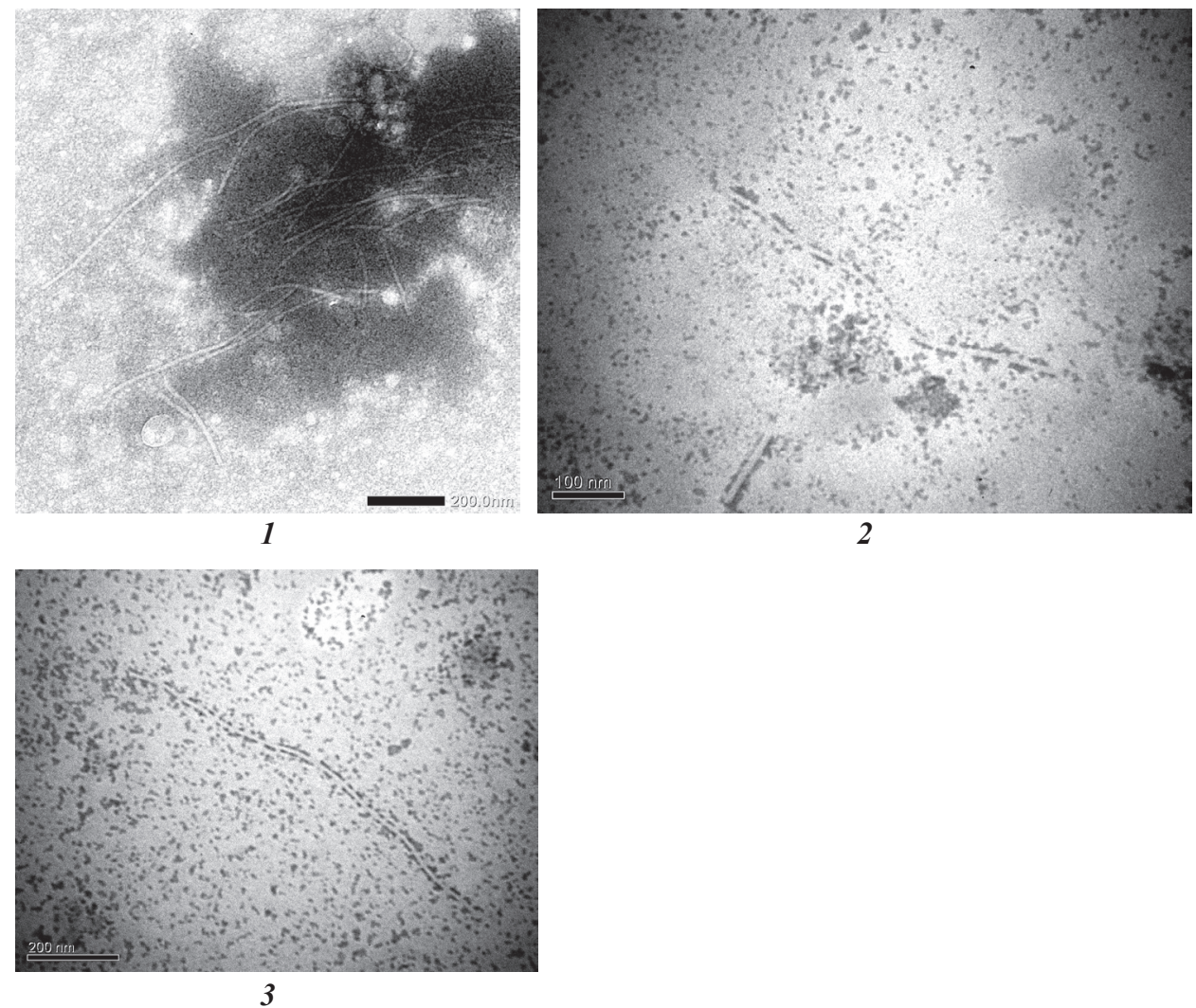

Fig. 4. Electron microscopy picture of Soybean mosaic virus isolates detected in soybean samples from left-bank Ukraine: 1 - 620-650 nm (JEM-1400); 2 - 530-550 nm;

$$
3 \text { - 800-820 nm (JEM-1230) }
$$

To investigate the belonging to strain clusters and genetic relatedness of studied SMV isolate with already known and described in the literature, we have conducted the RT-PCR. RT-PCR showed the presence of Soybean mosaic virus in the sample №17 from Poltava region (Pol-17), as evidenced by the presence in agarose gel amplicons of appropriate size (194 bp) (Fig 5).

Phylogenetic analysis of the nucleotide sequence of the part of capsid protein gene (positions 9505-9699 bp) of SMV isolate from Poltava region

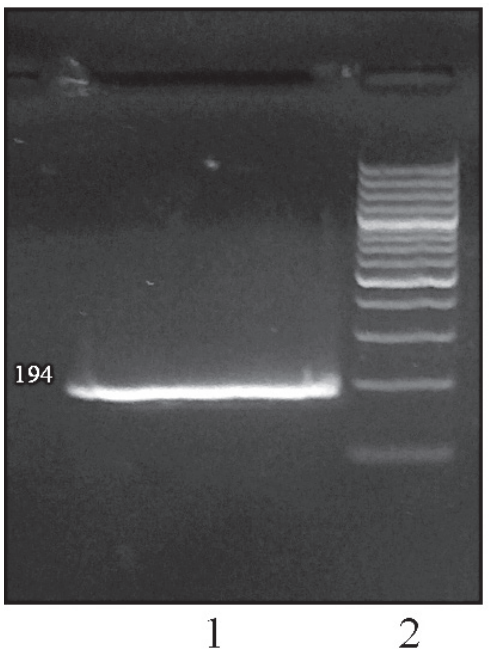

Fig. 5. The electrophoregram of RT-PCR products: 1 - cDNA, soybean sample № 17, Poltava region.

Product size - 194 bp; 2 - markers (100 bp, Fermentas) 
(Pol-17) and 36 isolates and strains of this virus (Table 1) showed a 100\% level of homology between the Ukrainian representative isolate with a number of Asian, European and American isolates (Fig. 6).

Table 1.

Identity of CP gene nucleotide sequences between Ukrainian SMV isolate Pol-17 and known strains of this virus

\begin{tabular}{|c|c|c|c|c|c|c|}
\hline & $\begin{array}{c}\text { SMV } \\
\text { Isolate/ } \\
\text { strain }\end{array}$ & $\begin{array}{c}\text { GenBank } \\
\text { accession } \\
\text { No }\end{array}$ & Country & Host & References & $\begin{array}{c}\text { Similari- } \\
\text { ties to Pol- } \\
17 \text { isolate, } \\
\%\end{array}$ \\
\hline 1. & HB-S19 & KR065491 & China & Glycine $\max$ & $\begin{array}{c}\text { Lin et al., } \\
\text { Unpublished }\end{array}$ & 100 \\
\hline 2. & HB-S23 & KR065495 & China & Glycine max & $\begin{array}{c}\text { Lin et al., } \\
\text { Unpublished }\end{array}$ & 100 \\
\hline 3. & HB-S25 & KR065497 & China & Glycine max & $\begin{array}{c}\text { Lin et al., } \\
\text { Unpublished }\end{array}$ & 99,3 \\
\hline 4. & HB-S27 & KR065499 & China & Glycine max & $\begin{array}{c}\text { Lin et al., } \\
\text { Unpublished }\end{array}$ & 100 \\
\hline 5. & XFQ001 & KP710871 & China & Glycine $\max$ & {$[16]$} & 97,9 \\
\hline 6. & XFQ010 & KP710874 & China & Glycine $\max$ & {$[16]$} & 99,3 \\
\hline 7. & XFQ014 & KP710876 & China & Glycine $\max$ & [16] & 100 \\
\hline 8. & LJZ002 & KP710865 & China & Glycine $\max$ & {$[16]$} & 95,6 \\
\hline 9. & LJZ010 & KP710866 & China & Glycine $\max$ & {$[16]$} & 95,6 \\
\hline 10. & SC7-N & KP710868 & China & Glycine max & [16] & 95,6 \\
\hline 11. & $\mathrm{ChS}$ & AH008450 & China & Glycine $\max$ & {$[17]$} & 100 \\
\hline 12 & SX-Z & KP710870 & China & Glycine $\max$ & {$[16]$} & 99,3 \\
\hline 13. & $\mathrm{~A}$ & KM886930 & Poland & Glycine $\max$ & [18] & 95,6 \\
\hline 14. & $\mathrm{M}$ & KM886929 & Poland & Glycine $\max$ & [18] & 100 \\
\hline 15. & Ar33 & KF297335 & Iran & Glycine $\max$ & [19] & 100 \\
\hline 16. & Go11 & KF135491 & Iran & Glycine $\max$ & [19] & 100 \\
\hline 17. & Lo3 & KF135490 & Iran & Glycine $\max$ & [19] & 100 \\
\hline 18. & strain 452 & AY216485 & USA & Glycine $\max$ & [17] & 100 \\
\hline 19. & VA2 & AF200584 & USA & Glycine $\max$ & [17] & 99,3 \\
\hline 20. & strain 1083 & AY216481 & USA & Glycine $\max$ & [17] & 99,3 \\
\hline 21. & G1 & FJ640977 & USA & Glycine $\max$ & [20] & 95,6 \\
\hline 22. & G2 & S42280 & USA & Glycine max & {$[20]$} & 94,1 \\
\hline 23. & G3 & FJ640978 & USA & Glycine max & {$[20]$} & 95,6 \\
\hline 24. & G6 & AF200569 & USA & Glycine $\max$ & [17] & 95,6 \\
\hline 25. & $\mathrm{~L}$ & EU871724 & Canada & Glycine $\max$ & [21] & 94,1 \\
\hline 26. & L-RB & EU871725 & Canada & Glycine $\max$ & [21] & 93,3 \\
\hline 27. & NP-C-L & HQ166265 & Canada & Glycine $\max$ & [22] & 91,8 \\
\hline 28. & NP-L & HQ166266 & Canada & Glycine $\max$ & [22] & 94,1 \\
\hline 29. & G5H & FJ807701 & South Korea & Glycine $\max$ & {$[23]$} & 95,6 \\
\hline 30. & strain G6H & FJ640981 & South Korea & Glycine $\max$ & [23] & 95,6 \\
\hline 31. & WS101 & FJ640957 & South Korea & Glycine soja & [23] & 95,6 \\
\hline 32. & WS32 & FJ640954 & South Korea & Glycine soja & [23] & 95,6 \\
\hline 33. & $\begin{array}{l}\text { severe } \\
\text { strain }\end{array}$ & AJ312439 & China & $\begin{array}{l}\text { Pinellia } \\
\text { ternata }\end{array}$ & {$[24]$} & 97,9 \\
\hline 34. & $\mathrm{Am}$ & KC845322 & China & $\begin{array}{c}\text { Atractylodes } \\
\text { macrocephala }\end{array}$ & \begin{tabular}{|c|} 
Niu Y.B., 2013 \\
Unpublished \\
\end{tabular} & 88,5 \\
\hline 35. & $\mathrm{NN}$ & KF982784 & China & $\begin{array}{c}\text { Pinellia } \\
\text { pedatisecta }\end{array}$ & $\begin{array}{c}\mathrm{Lu} \\
\text { Unpublished }\end{array}$ & 80,7 \\
\hline 36. & $\mathrm{HZ1}$ & AJ628750 & China & $\begin{array}{c}\text { Pinellia } \\
\text { ternata }\end{array}$ & {$[25]$} & 85,2 \\
\hline
\end{tabular}




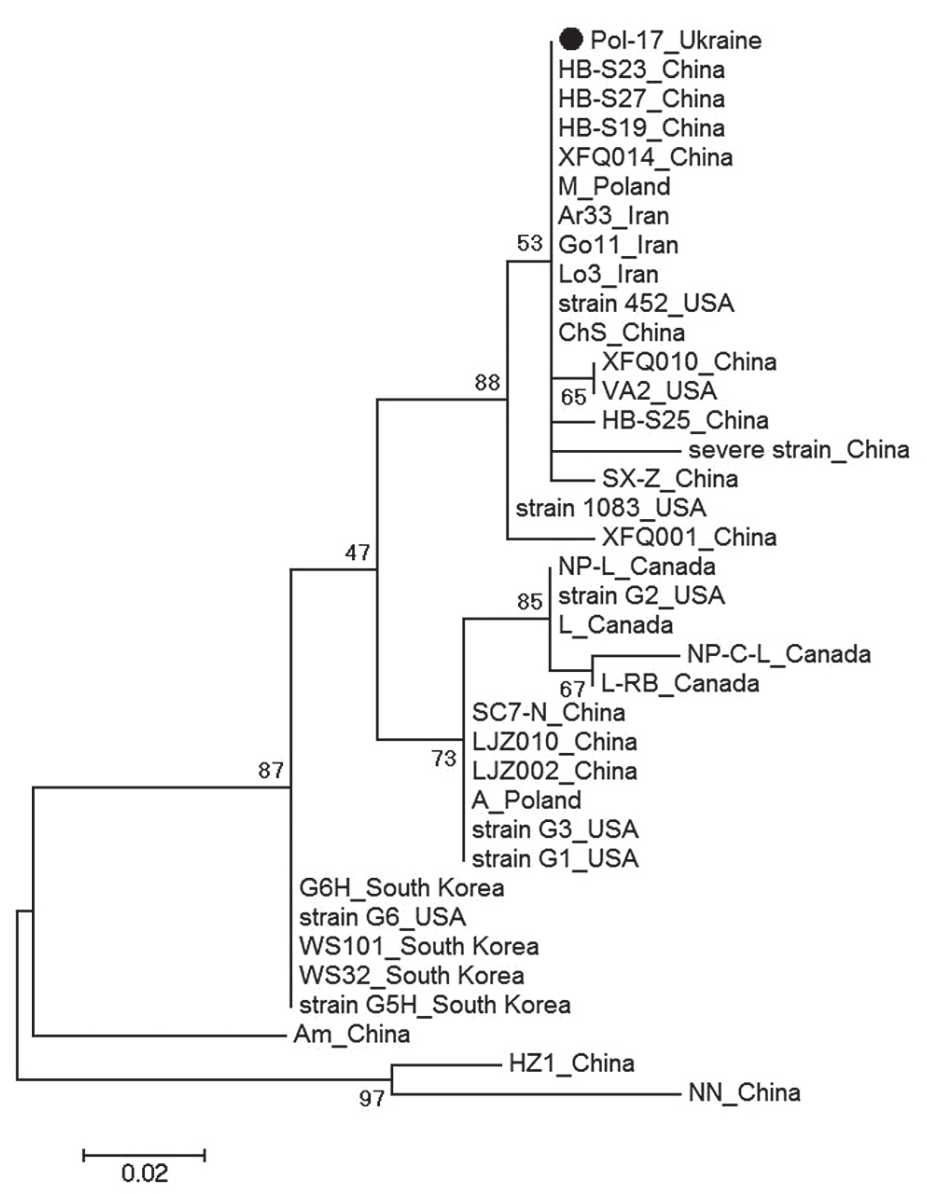

Fig. 6. Maximum likelihood (ML) tree resulting nucleotide sequences of part of the CP gene of Ukrainian isolate Pol-17 and different isolates from other countries (names and GenBank accession numbers are given in Table 1). The phylogenetic tree was constructed applying Jukes-Cantor model

As is evident from the phylogenetic tree, isolate Pol-17 belong to the one cluster and has a common origin with Chinese isolates HB-S19, HB-S23, HB-S27, SX-Z, XFQ014, ChS, Iranian and M isolate of Polish and American strain 452 (Fig. 6).

Topology of the tree constructed using nucleotide sequences of the part of SMV capsid protein gene was very similar to that recently described for compete genome sequences of SMV isolates [16]. According to this classification, 83 isolates were divided into four clades - from I to IV. According to it, isolate Pol-17, that has $100 \%$ homology with the Chinese isolate XFQ014, belongs to clade IV, together with Iranian isolates Ar33, Go11, Lo3 and Canadian isolates L, L-RB, NP-C-L, NP-L.

This is the first phylogenetic analysis of SMV isolate from the left bank of Ukraine. Earlier Sherepitko et al. isolated SMV from soybean on the right bank of the country (Vinnytsia region). It was investigated that Ukrainian isolate SMV (UA1Gr) for sequences of the coat protein coding region and P1 coding region has strong genetic relationships with SMV-VA2 isolate which together were sorted in one clade with G2 strain [5]. However, we cannot include Ukrainian isolate $\mathrm{UA} 1 \mathrm{Gr}$ to our analysis because studied areas of $\mathrm{CP}$ gene do not overlap. 
Discussion. For the first time observation of soybean crops in the fields of left-bank forest-steppe of Ukraine (Poltava, Sumy and Kharkiv region) on the presence of viral diseases is carried out. Pathogen that causes symptoms of rugosity and clearly marked dark green bloating on the leaves was identified (ELISA). It was found that $48 \%$ of tested samples are affected with Soybean mosaic virus. This is the first report about detection of this virus on soybean in a left-bank of Ukraine. Due to the reports about previously detection of mixed infection of SMV with Alfalfa mosaic virus [10] or Bean yellow mosaic virus [4] in Kyiv, Cherkassy and Vinnitsa regions, 29 of soybean samples were tested on their presence. ELISA results showed no antigens BYMV and AMV in all tested samples.

Our research showed that SMV isolates from the Poltava and Sumy regions had a size of 500 to $850 \times 13-17 \mathrm{~nm}$. So, the length of virions differs from previously isolated SMV in Ukraine. According to the literature, the Ukrainian SMV isolates have sizes of $750 \pm 25 \mathrm{~nm}$ [3], 650-750 $\times 17-18 \mathrm{~nm}$ [10], 700-760 nm [4].

Phylogenetic analysis of the nucleotide sequence of the capsid protein gene of Soybean mosaic virus showed a high level of phylogenetic relatedness between the representative Ukrainian isolate and Chinese, Iranian isolates, American isolate 452, and Polish isolate $\mathrm{M}$, which testifies to their common origin.

Results of our phylogenetic analysis as the data of many other authors $[5,17,18,20,23]$ testifies about absence of clear correlation between genetic differentiation and geographical origin that can be explained with the processes described for the SMV recombination between its various strains.

So, Seo et al. $[20,23]$ analyzed the 44 SMV isolates and strains and did not provide clear clues for classifying the SMV population according to geographical origins. All known isolates/strains they are largely divided into two geographic subpopulations, Far East Asia and North America.

Soybean originated in East Asia and has been cultivated for several thousands of years, and it was recently suggested that SMV, like soybean itself, originated in South East Asia when it diverged from WMV around1500 years ago, and further diverged into the soybean and Pinellia lineages around a 1000 years ago [26]. However, in North America, soybean was first introduced in 1765 and has been widely spread there in the early twentieth century. As soybean is the natural host of SMV in fields, the history of the virus in North America is believed to be similar to that of soybean [20, 23]. Comparison of nucleotide diversities of within- or between-population also revealed that little genetic differentiation has occurred between two geographical subpopulations. Thus, it is likely that few sequence diversity have yet accumulated in SMV population of North America. This, taken together with our phylogenetic results, also suggests that not much genetic drift has occurred in the SMV population. On the other hand, the involvement of such human activities as trade of SMV-infected soybean seed or relatively recent spread of the virus from Asia on a global scale can be another possible reason for phylogenetic inconsistency on geographical clustering [20, 23].

Results show that SMV isolates have a high level of homology among themselves and the most significant difference was found between strains from Far East Asia and North America, which made it possible to divide them into 
two geographical subpopulations. It should be noted that some authors speak of a great genetic variability of isolates form, a variety of symptoms and severity of the disease than North American isolates that may be associated with a much older cultivation of soybean in China (more than 2 thousand years ago), and then for a long time and the evolution of SMV strains in the region.

Obtained in this study data about affecting of soybeans in three regions of Ukraine by SMV indicate about detection of the pathogen in large soybean producing areas of the country that can be a significant danger to agriculture, given that the virus can cause epiphytoties and reducing of seed quality of this crop.

\section{Міценко Л.Т. ${ }^{1}$, Дуніч А.А. ${ }^{,}$, Невченко Т.П. ${ }^{,}$Будзанівська I.Г. ${ }^{1}$, Поліщук В.П. ${ }^{1}$, Андрійчук О.М. ${ }^{1}$ Молчанець О.В. ${ }^{1}$, Антіпов I.O. ${ }^{2}$ \\ ${ }^{1}$ ННЦ «Інститут біології та медиизини», Київський національний університет імені Тараса Шевченка, вул. Володимирська, 64/13, Київ, 01601, Україна, \\ ${ }^{2}$ Національний університет біоресурсів і природокористування, вул. Героїв оборони, 15, Київ, 03041,Україна \\ ВИЯВЛЕННЯ ВІРУСУ МОЗАЇКИ СОЇ В ДЕЯКИХ ОБЛАСТЯХ ЛІВОБЕРЕЖНОГО ЛІСОСТЕПУ УКРАЇНИ}

\section{Резюме}

Соя (Glycine $\max$ L.) є стратегічною зернобобовою культурою світового землеробства XXI століття, яка перебуває в центрі уваги світової аграрної науки і виробництва. Вірус мозаїки сої (ВМС) є збудником однієї з основних та найбільш шкодочинних вірусних хвороб, яка поширена в агроценозах усіх соєсіючих регіонів світу. Інфікування рослин сої ВМС призводить до значних втрат врожаю та спричиняє зниження якості насіння та життєздатності сходів. Дослідження вірусів сої в Україні були проведені виключно на Правобережній ії частині. Однак, виявлення та можливого поширення і циркуляції цих вірусів в умовах Лівобережного Лісостепу дотепер не проводилося. Мета. Провести діагностику та ідентифікацію вірусів, які уражують сою на території Лівобережної України, та дослідити деякі з їх властивостей. Методи: візуальна діагностика, трансмісійна електронна мікроскопія, імуноферментний аналіз, виділення тотальної РНК із рослинного матеріалу, полімеразна ланцюгова реакція, сиквенування, філогенетичний аналіз. Результати. Досліджено 29 зразків рослин сої на території Лівобережного Лісостепу України (Полтавська, Сумська і Харківська області) на наявність вірусної інфекції. Методом ІФА встановлено, що 48\% зразків (13 зразків із Полтавської області та 1 - з Сумської) уражені вірусом мозаїки сої. Це перше повідомлення про ураження ВМС сої, вирощеної в умовах Лівобережної України. Зважаючи на раніше представлені дані щодо циркуляції на території Правобережної частини країни змішаної інфекції цього вірусу із вірусом жовтої мозаїки квасолі (ВЖМК) та вірусом мозаїки люцерни (ВМЛ), досліджувані зразки були нами перевірені на наявність і цих збудників. Результати аналізу показали відсутність антигенів ВЖМК і ВМЛ. Встановлено, що досліджувані ізоляти ВМС відрізняються за розмірами віріонів від виділених раніше в Україні ізолятів вказаного збудника. Філогенетичний аналіз нуклеотидних послідовностей ділянки гена капсидного білка вірусу мозаїки сої виявив 100\% рівень філогенетичної спорідненості між репрезентативним українським ізолятом та китайськими, іранськими 
ізолятами, а також американським ізолятом 452 і польським ізолятом М, що свідчить про їх спільне походження.

Ключові слова: Glycine max, вірус мозаїки сої, вірус мозаїки люцерни, вірус жовтої мозаїки квасолі, імуноферментний аналіз, ПЛР, сиквенування, морфологія вірусів, філогенетичний аналіз.

Мищенко Л.Т. ${ }^{1}$, Дунич А.А. ${ }^{1}$, Шевченко Т.П. ${ }^{1}$, Будзанивская И.Г. ${ }^{1}$,
Полищук В.П. ${ }^{1}$, Андрийчук Е.Н. ${ }^{1}$, Молчанец О.В. ${ }^{1}$, Антипов И.А.

${ }^{1}$ ОНЦ «Институт биологии и медицины», Киевский национальный университет имени Тараса Шевченко, ул. Владимирская, 64/13, Киев, 01601, Украина

${ }^{2}$ Национальный университет биоресурсов и прородопользования, ул. Героев Обороны, 15, Киев, 03041, Украина

\title{
ВЫЯВЛЕНИЕ ВИРУСА МОЗАИКИ СОИ В НЕКОТОРЫХ ОБЛАСТЯХ ЛЕВОБЕРЕЖНОЙ ЛЕСОСТЕПИ УКРАИНЫ
}

\author{
Резюме
}

Coя (Glycine max L.) является стратегической зернобобовой культурой мирового земледелия XXI века, которая находится в центре внимания мировой аграрной науки и производства. Вирус мозаики сои (ВМС) является возбудителем одного из основных и наиболее вредоносных вирусных заболеваний, которое распространено в агроценозах всех соесеющих регионов мира. Инфицирование растений сои ВМС приводит к значительным потерям урожая, снижению качества семян и жизнеспособности всходов. Исследования вирусов сои в Украине были проведены исключительно на Правобережной ее части. Однако, исследования возможного распространения и циркуляции этих вирусов в условиях Левобережной Лесостепи до сих пор не проводилось. Цель. Провести диагностику вирусов, которые поражают сою на территории Левобережной Украины, и исследовать некоторые из их свойств. Методы: визуальная диагностика, трансмиссионная электронная микроскопия, иммуноферментный анализ, выделение тотальной РНК из растительного материала, полимеразная цепная реакция, сиквенирование, филогенетический анализ. Результаты. Исследовано 29 образцов растений сои на территории Левобережной Лесостепи Украины (Полтавская, Сумская и Харьковская области) на наличие вирусной инфекции. Методом ИФА установлено, что 48\% образцов (13 образцов из Полтавской области и 1 - из Сумской) поражены вирусом мозаики сои. Это первое сообщение о поражении ВМС сои, выращенной в условиях Левобережной Украины. Исходя из ранее представленных данных о циркуляции на территории Правобережной части страны смешанной инфекции этого вируса с вирусом желтой мозаики фасоли (ВЖМФ) и вирусом мозаики люцерны (ВМЛ), исследуемые образцы были нами проверены на наличие и этих возбудителей. Результаты анализа показали отсутствие антигенов ВЖМФ и ВМЛ. Установлено, что исследуемые изоляты ВМС отличаются по размерам вирионов от выделенных ранее в Украине изолятов указанного возбудителя. Филогенетический анализ нуклеотидных последовательностей участка гена капсидного белка вируса мозаики сои показал $100 \%$ уровень филогенетического родства между репрезентативным украинским изолятом и китайскими, иранскими изолятами, а также американским изолятом 452 и польским изолятом М, что свидетельствует об их общем происхождении. 
Ключевые слова: Glycine max, вирус мозаики сои, вирус мозаики люцерны, вирус желтой мозаики фасоли, иммуноферментный анализ, ПЦР, сиквенирование, морфология вирусов, филогенетический анализ.

1. Clinton GP. Reports of the botanist for 1915: Soybeans. Annual Report, Connecticut Agricultural Experiment Station. 1916: 446.

2. Gardner MW, Kendrick JB. Soybean mosaic virus. Journal of Agricultural Research. 1921; 22: 111-14.

3. Bilyk LG. [Soybean mosaic in Ukraine]. Thesis PhD. Kyiv; 1967. Ukrainian

4. Kyrychenko AM, Kraeva GV, Kovalenko OG. Biological characteristic and identification of soybean virus isolated from different Ukraine regions. Mikrobiol. Zh. 2012; 74(1): 46-50. PubMed PMID: 22545444.

5. Sherepitko DV, Budzanivska IG, Polischuk VP, Boyko AL. Sequencing and phylogenetic analysis of Soybean mosaic virus isolated in Ukraine. Biopolym. Cell. 2011; 27(6):472-79. http://dx.doi.org/10.7124/bc.00011A

6. Wang A. Soybean mosaic virus: research progress and future perspectives. In: Proceedings of VIII World Soybean Research Conference; 2009 Ast 10-15; Beijing, China.

7. Arif M, Hassan S. Evaluation of resistance in soybean germplasm to Soybean mosaic potyvirus under field conditions. Online Journal of Biological Sciences. 2002; 2:601604. Doi: $10.3923 /$ jbs.2002.601.604

8. Liao L, Chen P, Buss GR, Yang Q, Tolin SA. Inheritance and allelism of resistance to Soybean mosaic virus in Zao18 soybean from China. Buss Journal of Heredity. 2002; 93(6):447-52. PubMed PMID: 12642647.

9. El-Amretz AA, El-Said HM, Salem DE. Effect of Soybean mosaic virus infection on quality of soybean seed. Agricultural Research Review. 1987; 63:155-64.

10. Sherepitko DV. Molecular-genetic and biological properties of viruses (soybean mosaic potyvirus, alfalfa mosaic alfamovirus) identified on soybean under environmental conditions of Forest-steppe zone of Ukraine. Thesis PhD. Kyiv; 2012. Ukrainian.

11. Peresypkin VF, Markov IL, Shelestova VS. [Workshop on the basics of research in plant protection]. K; 2000. Ukrainian.

12. Salyga YuT, Snitynsky VV. Elektronna mikroskopiya biologichnyh obyektiv. Kyiv: Svit; 1999. Ukrainian.

13. Crowther JR. ELISA. Theory and practice. New York: Hamana Press; 1995.

14. Melnichuk MD, Antipov IO, Spiridonov VG. Molekulyarna diagnostyla ta identyfikatcia X-, Y-, M-, S-, L- virusiv kartopli (Solanum tuberosum L.) metodom polimeraznoyi lantcyugovoyi reaktcii. Metodychni rekomendatcii. Kyiv: Publish center NAU; 2008. Ukrainian.

15. Lakin GF. [Biometry]. M: High school; 1980. Russian.

16. Zhou G-C, Shao Z-Q, Ma F-F, Wu P, Wu X-Y, Xie Z-Y, et al. The evolution of soybean mosaic virus: An updated analysis by obtaining 18 new genomic sequences of Chinese strains/isolates. Virus Res. 2015; 208:189-98. PubMed PMID: 26103098.

17. Domier LL, Latorre IJ, Steinlage TA, McCoppin N, Hartman GL. Variability and transmission of Aphis glycines of North American and Asian soybean mosaic virus isolates. Arch Virol. 2003; 148:1925-41. PubMed PMID: 14551816.

18. Jezewska M, Trzmiel K, Zarzyn'ska-Nowak A, Lewandowska M. Identification of Soybean mosaic virus in Poland. Journal of Plant Pathology. 2015; 97(2): 357-62. doi: 10.4454/JPP.V97I2.006. 
19. Ahangaran A, Habibi MK, Mohammadi GH, Winter S, Garcia-Arenal F. Analysis of Soybean mosaic virus genetic diversity in Iran allows the characterization of a new mutation resulting in overcoming Rsv4-resistance. Journal of General Virology. 2013; 94: 2557-68. PubMed PMID: 23939982.

20. Seo JK, Ohshima K, Lee HG, Son M, Choi HS, Lee SH, et al. Molecular variability and genetic structure of the population of Soybean mosaic virus based on the analysis of complete genome sequence. Virology. 2009b; 393: 91-103. PubMed PMID: 19716150.

21. Gagarinova AG, Babu M, Poysa V, Hill JH, Wang A. Identification and molecular characterization of two naturally occurring Soybean mosaic virus isolates that are closely related but differ in their ability to overcome Rsv4 resistance. Virus Research. 2008; 138: 50-56. PubMed PMID: 18793685.

22. Chowda-Reddy RV, Sun H, Chen H, Poysa V, Lin H, Gijzen M, et al. Mutations in the P3 protein of Soybean mosaic virus G2 isolates determine virulence on Rsv4-genotype soybean. Molecular Plant Microbe Interaction. 2011; 24: 37-43. PubMed PMID: 20795856.

23. Seo JK, Lee HG, Choi HS, Lee SH, Kim KH. Infectious in vivo transcripts from a fulllength clone of Soybean mosaic virus strain G5H. Plant Pathol J. 2009; 25:54-61.

24. Chen J, Zheng H, Lin L, Adams MJ, Antoniw JF, Zhao MF, et al. A virus related to Soybean mosaic virus from Pinellia ternata in China and its comparison with local soybean SMV isolates. Archives of Virology. 2004; 149: 349-63. PubMed PMID: 14745600.

25. Shi YH, Hong XY, Chen J, Adams MJ, Zheng HY, Lin L, et al. Further molecular characterisation of potyviruses infecting aroid plants for medicinal use in China. Arch. Virol. 2005; 150(1): 125-35. PubMed PMID: 15449140.

26. Gibbs AJ, Trueman JW, Gibbs MJ. The Bean common mosaic virus lineage of potyviruses: where did it arise and when? Arch. Virol. 2008; 153:2177-87. PubMed PMID: 19030956.

Отримано 12.09.2016 